\title{
Hippocrates Was Right: Now What? Water As a Part of Healthy Aging
}

\author{
Evan C. Johnson \\ Human Integrated Physiology Laboratory University of Wyoming, Laramie, WY, USA
}

\section{Keywords}

Aging $\cdot$ Disease $\cdot$ Metabolism $\cdot$ Water recommendations

\begin{abstract}
Background: Aging is defined as the progressive organism change leading to debility, disease, and death [1]. We know that as we age, our risk increases for diseases such as diabetes, cancer, and chronic kidney disease, and many of our homeostatic processes change as well, such as cell signaling, metabolism, and proteostasis [2]. The data clearly show that water intake decreases with aging, especially after age 60 years [3]. However, the question becomes "Do we drink less because we age, or do we age because we drink less?" (Fig. 1). Summary: There are data to support both directions of this hypothesis. One example supporting that water intake decreases due to aging is that in older adults, the thirst response to hyperosmotic and hypovolemic stimuli is blunted in comparison to younger adults [4]. However, we are in-
\end{abstract}

creasingly gathering data to also support that low water intake can be a contributor to both disease and altered cellular processes, potentially accelerating aging related dysfunction. For example, in older adults, low water intake has been shown to be associated with working memory [5], blood glucose regulation [6], incidence of stroke [7], and falls [8] (i.e., dementia, diabetes, cardiovascular disease, and mobility). Additionally, processes such as metabolism [9], cell signaling [10], and muscle damage following exercise [11] have also been linked to hydration. Key messages are that it is clear that water intake changes as we age, primarily due to changes in thirst. However, what is our duty as hydrationists is to begin to evaluate both directions of the aging, dysfunction, and water intake relationship (Fig. 1). Just as we have begun to realize the influence as water as a nutrient, we can hopefully demonstrate how a simple intervention like drinking to recommendations can be a part of healthy aging for all.

(c) 2022 The Author(s).

Published by S. Karger AG, Basel karger@karger.com www.karger.com/anm

Karger $\stackrel{\text { ' }}{5}$

BOPEN ACCESS
C 2022 The Author(s).

Published by S. Karger AG, Basel

This article is licensed under the Creative Commons Attribution 4.0 International License (CC BY) (http://www.karger.com/Services/ OpenAccessLicense). Usage, derivative works and distribution are permitted provided that proper credit is given to the author and the original publisher.
Correspondence to:

Evan C. Johnson, evancjohnson@gmail.com 
Fig. 1. Solid lines represent established causal relationships between different physiological states and behaviors. Dashed lines represent proposed, supported, but unproven relationships.

\section{Conflict of Interest Statement}

\section{Funding Sources}

E.C. Johnson is a member of the scientific advisory board for Danone. In the past, E.C. Johnson has received research funding, travel expense reimbursement, and consulting fees from Danone.

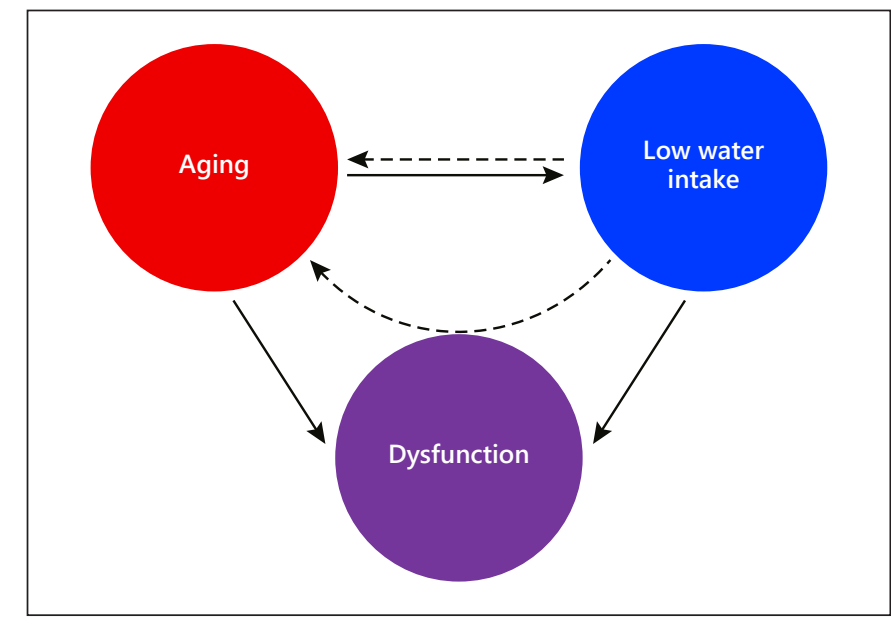

This presentation was supported by funding from Danone Research.

\section{References}

1 Rogers K, Guarente LP, Simic P. Aging. Encyclopedia Britannica. 2020. Epub ahead of print.

2 National Institute on Aging. Geroscience: The intersection of basic aging biology, chronic disease, and health. US Department of Health \& Human Services; 2016.

3 Rosinger A, Herrick K. Daily water intake among US men and women, 2009-2012. NCHS data brief, no 242. Hyattsville: National Center for Health Statistics; 2016.

4 Kenney WL, Chiu P. Influence of age on thirst and fluid intake. Med Sci Sports Exerc. 2001; 33(9):1524-32.
5 Suhr JA, Patterson SM, Austin AW, Heffner $\mathrm{KL}$. The relation of hydration status to declarative memory and working memory in older adults. J Nutr Health Aging. 2010 Dec;14(10): 840-3.

6 Burge MR, Garcia N, Qualls CR, Schade DS. Differential effects of fasting and dehydration in the pathogenesis of diabetic ketoacidosis. Metabolism. 2001 Feb;50(2):171-7.

7 Leurs LJ, Schouten LJ, Goldbohm RA, van den Brandt PA. Total fluid and specific beverage intake and mortality due to IHD and stroke in the Netherlands Cohort Study. Br J Nutr. 2010 Oct;104(8):1212-21.
8 Hamrick I, Norton D, Birstler J, Chen G, Cruz L, Hanrahan L. Association between dehydration and falls. Mayo Clin Proc Innov Qual Outcomes. 2020;4(3):259-65.

9 Vanhaecke T, Perrier ET, T, Melander O. A journey through the early evidence linking hydration to metabolic health. Ann Nutr Metab. 2020;76 Suppl 1:4-9.

10 Häussinger D. The role of cellular hydration in the regulation of cell function. Biochem J. 1996 Feb 1;313(Pt 3):697-710.

11 Cleary MA, Sweeney LA, Kendrick ZV, Sitler MR. Dehydration and symptoms of delayedonset muscle soreness in hyperthermic males. J Athl Train. 2005;40(4):288-97. 